\title{
Efficacy and Maternal Comfort of Sequential versus Simultaneous Breast Expression by Mothers of Critically III Newborns
}

\author{
Kritik Hasta Yenidoğanların Annelerinde Ardıșık ve Eș Zamanlı Süt \\ Sağmanın Etkinlik ve Konforu
}

\author{
Özge Altun Köroğlu, Nazmiye Can, Başak Yıldız Atıkan, Sema Tanrıverdi, Mehmet Yalaz, \\ Mete Akısü, Nilgün Kültürsay \\ Ege University Faculty of Medicine, Department of Pediatrics, Division of Neonatology, Izmir, Turkey
}

\section{ABSTRACT}

Aim: Expressed breast milk is beneficial for infants in neonatal intensive care unit (NICU) when direct breastfeeding is not possible. Breast expression with manual or electric breast pumps is promoted for the initiation and maintenance of lactation in this critical period. In this study, we aimed to compare the efficacy and maternal comfort of sequential versus simultaneous breast expression in newly delivered mothers whose infants were admitted to NICU.

Materials and Methods: Thirty five mothers were followed prospectively for milk expression either sequentially ( $\mathrm{n}=21$, group 1 ) or simultaneously ( $\mathrm{n}=14$, group 2) with breast pumps for 10 days. The total amount of milk expressed per day and per each period was recorded together with the duration of breast expression. The mothers' impressions about the easiness and comfort of the procedure, and their satisfaction with the amount of milk were evaluated with a questionnaire at the end of the study.

Results: The amounts of expressed milk per day and per each expression period were similar in both groups. However, time spent for each expression period was significantly lower in the simultaneous breast expression group. Mothers in this group gave higher scores with regard to ease of use when compared to mothers in the sequential expression group ( $4.36 \pm 0.50$ vs. $4.00 \pm 0.44, p=0.046$ ). The mothers graded both methods with similar scores in all other parameters. Conclusion: Simultaneous breast expression is time saving while both simultaneous and sequential breast expression are similarly efficient for milk production, and both methods are helpful and tolerable in promoting breastfeeding for NICU mothers.

Keywords: Breastfeeding, breast pump, sequential, simultaneous, neonatal intensive care unit
ÖZ

Amaç: Yenidoğan yoğun bakım ünitesinde (YYBÜ) yatan bebeklerde direkt emzirme mümkün olmasa da sağımış anne sütü çok faydalıdır. Bu kritik dönemde laktasyonun başlatılması ve sürdürülmesi için elle ya da elektrikli süt pompaları kullanılarak süt sağılması önerilir. Bu çalışmada bebekleri YYBÜ'ye yatııılan yeni doğum yapmış annelerde ardısıı ve eş zamanlı süt sağmanın etkinlik ve konforunu karşlaş̧ırmayı amaçladık.

Gereç ve Yöntemler: Çalışmaya alınan 35 anne, elektrikli pompa kullanarak her iki memeden ardşsık ( $n=21$ ) ya da eş zamanlı ( $n=14)$ süt sağdıkları 10 gün içerisinde prospektif olarak izlendi. Süt sağma süresine ek olarak sağllan süt miktarı günlük ve her sağma için ayrı ayrı kaydedildi. Bu uygulamaların kolaylığı ve konforu konusunda annelerin görüșleri ve tatminkarıkları çalıșmanın sonunda bir anket ile değerlendirildi.

Bulgular: Günlük ve her sağma girişiminde elde edilen süt miktarları gruplar arasında benzer bulundu. Her iki memeden eş zamanlı süt sağan annelerin süt sağma süreleri anlamlı olarak daha kısa bulundu. Eş zamanlı olarak her iki memeden süt sağan anneler diğerleri ile karşılaştırıldılarında; kullanım kolaylığı yönünden daha yüksek skorlar verdiler $(4,36 \pm 0,50$ ye karşı $4,00 \pm 0,44, p=0,046)$. Anketin diğer alanlarında her iki süt sağma tekniği de benzer bulundu. Sonuç: Süt sağmak için her iki memenin eş zamanılı sağıması zaman kazandırııı bir yöntemdir. Bununla beraber hem eş zamanlı hem de ardışık süt sağma yöntemleri; bebekleri YYBÜ'de yatan annelerde laktasyonun sağlanmasında etkin ve iyi tolere edilen yöntemlerdir.

Anahtar Kelimeler: Süt sağma, süt pompası, ardışık, eş zamanlı, yenidoğan yoğun bakım ünitesi 


\section{Introduction}

American Academy of Pediatrics recommends the baby's own mother's milk as the primary nutrient for both term and preterm neonates (1). Mother's milk is beneficial for healthy newborns and is even lifesaving for sick preterm and term infants hospitalized in neonatal intensive care units (NICUs). The main benefits are listed as better tolerance of enteral feeds, prevention of necrotizing enterocolitis and systemic infections, and improvement in cognitive functions in these vulnerable infants (1-3). However, in NICUs, mothers are separated from their sick infants. Since they can not directly breastfeed during the serious illness period, this situation may negatively influence the initiation and maintenance of lactation (4). Early initiated and frequently applied emptying of the breasts by breast pumps along with the emotional support given to mothers may help to maintain and promote breastfeeding $(5,6)$. Frequent breast expression improves milk production and breastfeeding success in mothers of premature infants (7). Educating the mothers on the benefits of human milk and the methods for breast expression is necessary to achieve optimal milk production (8). Milk expression with breast pumps also enhances prolactin release and has a positive effect on the quantity of milk (9). Zinaman et al. (10) showed that prolactin and oxytocin hormone releases were similar in directly breastfeeding mothers compared to mothers who delivered prematurely and used electrically powered pumps for collecting milk.

Several types of manual or electrically powered breast pumps are now in use for breast milk expression. Some breast pumps have double pumps making simultaneous expression of both breasts possible. Other breast pumps with only one pump are used by mothers to express breast milk sequentially. Simultaneous or sequential use of breast pumps may affect the duration and comfort of the procedure. The aim of this study was to compare the efficiency and maternal comfort of sequential versus simultaneous breast expression in newly delivered mothers whose infants were admitted to NICU.

\section{Materials and Methods}

The mothers of infants who were hospitalized in Ege University Children's Hospital NICU were included in this study. These infants were not breastfed due to their illnesses and their mothers were encouraged to use breast pumps to collect their milk. Mothers who had any illness or taking any medication which is contraindicated or may influence breastfeeding were excluded from the study. All study group mothers were divided into two groups according to their preference of sequential or simultaneous breast expression by electric breast pumps (Lactaline; Ameda, Lincolnshire, IL, USA). Each mother was provided with a breast pump for her use at home. The mothers were motivated to empty their breasts as often as they could, and the duration of pumping, the amount of milk collected until the mother felt that her breasts were emptied were noted at each period for 10 days in a diary provided by the researchers. At the end of the study, the mothers were questioned on the easiness and comfort of the procedure with a questionnaire applied by face to face interviews. The questionnaire was designed to evaluate their impressions (easiness to use, comfort, presence of pain, general opinions) and their satisfaction with the milk amounts with a 5-point scale from 1 (very bad) to 5 (very good). Total scores were calculated by the summation of points given for each category. This study was approved by Ege University Faculty of Medicine Ethical Committee (approval number: 12-4/11). All participating mothers gave a written informed consent.

\section{Statistical Analysis}

Statistical analysis was carried out using SPSS 17.0. Chisquare and Mann-Whitney $U$ tests were used for statistical analysis. $\mathrm{P}<0.05$ was considered as statistically significant.

\section{Results}

Thirty five mothers were enrolled in the study. Maternal ages varied between 19 and 42 years $(30.8 \pm 5.7)$. Gestational ages of the infants varied between 25 to 38 weeks $(31.9 \pm 3.8)$ and their birth weights were within 760 and 3200 grams (1554.8 \pm 663.6$)$. Twenty one mothers preferred sequential milk expression using a single pump and fourteen mothers preferred simultaneous milk expression with double breast pumps. Since 5 mothers did not need to use breast pumps after the first two days, the study period for each mother varied between 2 and 10 days (mean \pm standard deviation: 7.55 \pm 2.7 ).

The mothers used the pumps 4-6 times a day. The type of the breast pump did not change the dropout rate of the study $(p=0.435)$. The daily frequency of using the pump was $5.42 \pm 0.67$ times in the sequential expression group, and $5.57 \pm 0.51$ times in the simultaneous expression group $(p=0.507)$.

The total amounts of milk obtained with sequential versus simultaneous breast expression are shown in Figure 1 and detailed data regarding milk expression over a 10-day

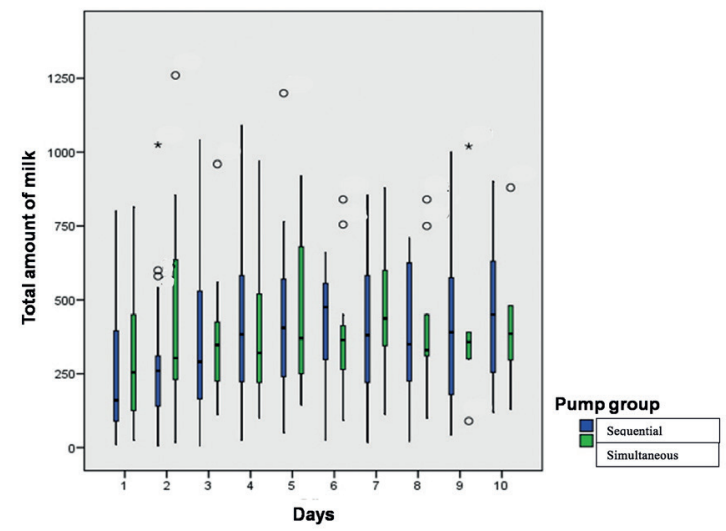

Figure 1. Total milk amounts obtained in one day with sequentia versus simultaneous breast expression 
study given in Table I. Although there was a tendency to obtain higher amounts of milk per day with simultaneous breast expression, no statistical difference was observed on any day between the two study groups. However, mothers in the simultaneous expression group achieved similar amounts of milk in shorter time periods.
Mothers in the simultaneous expression group gave higher scores regarding the ease of use than the mothers in the sequential expression group $(4.36 \pm 0.50$ vs. $4.00 \pm 0.44$, $p=0.046$ ). The mothers' scores for other parameters (comfort of the procedure, their general impressions, and their

\begin{tabular}{|c|c|c|c|c|}
\hline & Sequential & Simultaneous & Sequential & Simultaneous \\
\hline & \multicolumn{2}{|c|}{ Day 1 (n=35) } & \multicolumn{2}{|c|}{ Day $6(n=21)$} \\
\hline Total amount of expressed milk, mL & $251.38(217.33)$ & $325.79(272.11)$ & 416.25 (201.22) & $388.36(228.43)$ \\
\hline Milk collected at each use, $\mathrm{mL}$ & $51.83(38.71)$ & $70.71(55.66)$ & $73.33(35.6)$ & $77.00(37.40)$ \\
\hline Total time spent daily, min & $90.05(31.17)$ & $56.21(31.98)^{*}$ & $107.50(23.78)$ & $72.27(24.22)^{*}$ \\
\hline Time spent for each use, min & $18.90(2.86)$ & $11.57(3.45)^{\dagger}$ & $19.17(2.88)$ & $15.00(5.00)^{*}$ \\
\hline \multirow[t]{2}{*}{ Daily milk expression frequency } & $4.76(1.44)$ & $4.79(1.76)$ & $5.58(0.79)$ & $5.00(1.18)$ \\
\hline & \multicolumn{2}{|c|}{ Day $2(n=33)$} & \multicolumn{2}{|c|}{ Day 7 (n=20) } \\
\hline Total amount of expressed milk, mL & $298.81(432.86)$ & $432(344)$ & $408.09(250.01)$ & $465.80(215.16)$ \\
\hline Milk collected at each use, $\mathrm{mL}$ & $58.48(40.67)$ & $76.14(56.96)$ & $72.27(46.6)$ & $82.50(34.39)$ \\
\hline Total time spent daily, min & $101.00(28.91)$ & $76.43(26.48)^{*}$ & $121.82(16.6)$ & $79.5(26.08)^{\dagger}$ \\
\hline Time spent for each use, min & $19.19(2.60)$ & $13.57(4.56)^{\dagger}$ & $20.00(0.20)$ & $14.50(4.37)^{\dagger}$ \\
\hline \multirow[t]{2}{*}{ Daily milk expression frequency } & $5.29(1.27)$ & $5.71(0.82)$ & $5.91(1.04)$ & $5.50(0.85)$ \\
\hline & \multicolumn{2}{|c|}{ Day $3(n=30)$} & \multicolumn{2}{|c|}{ Day $8(n=15)$} \\
\hline Total amount of expressed milk, mL & $376.16(291.26)$ & $367.86(291.26)$ & $391.00(240.48)$ & $409.44(239.82)$ \\
\hline Milk collected at each use, $\mathrm{mL}$ & $71.21(57.85)$ & $66,36(40,61)$ & $69,64(41,80)$ & $78.00(41.93)$ \\
\hline Total time spent daily, min & $98.42(30.95)$ & $85.3(30.95)$ & $112.73(10.09)$ & $74.44(31.66)^{\dagger}$ \\
\hline Time spent for each use, min & $18.16(3.80)$ & $14.79(4.87)^{*}$ & $20.00(0.00)$ & $13.33(5.00)^{\dagger}$ \\
\hline \multirow[t]{2}{*}{ Daily milk expression frequency } & $5.10(1.58)$ & $5.79(0.69)$ & $5.64(0.50)$ & $5.56(1.13)$ \\
\hline & \multicolumn{2}{|c|}{ Day 4 (n=27) } & \multicolumn{2}{|c|}{ Day $9(n=15)$} \\
\hline Total amount of expressed milk, mL & $419.94(283.69)$ & $383.36(231.41)$ & $419.27(293.56)$ & $419.17(313.69)$ \\
\hline Milk collected at each use, $\mathrm{mL}$ & $83.81(64.51)$ & $77.50(45.32)$ & $71.82(48,53)$ & $74,00(50,66)$ \\
\hline Total time spent daily, min & $100.00(29.2)$ & $73.50(37.83)^{*}$ & $110.91(18.68)$ & $81.67(28.57)^{*}$ \\
\hline Time spent for each use, min & $17.31(5.37)$ & $14.50(4.84)$ & $19.55(1.50)$ & $15.00(5.47)^{*}$ \\
\hline \multirow[t]{2}{*}{ Daily milk expression frequency } & $5.38(1.02)$ & $5.29(1.38)$ & $5.82(0.40)$ & $5.50(0.54)$ \\
\hline & \multicolumn{2}{|c|}{ Day $5(n=24)$} & \multicolumn{2}{|c|}{ Day $10(n=15)$} \\
\hline Total amount of expressed milk, mL & $426.14(307.13)$ & $456.85(273.77)$ & $485.00(252.69)$ & $426.00(253.73)$ \\
\hline Milk collected at each use, $\mathrm{mL}$ & 75.79 (52.38) & $86.08(41.18)$ & $88.22(47.63)$ & $72.67(41.58)$ \\
\hline Total time spent daily, min & $103.57(24.05)$ & $81.77(32.89)$ & $111.11(10.54)$ & $83.33(26.58)^{*}$ \\
\hline Time spent for each use, min & $18.57(3.63)$ & $15.62(5.39)$ & $20.00(0.00)$ & $15.00(5.47)^{*}$ \\
\hline Daily milk expression frequency & $5.64(0.74)$ & $5.23(1.16)$ & $5.56(0.52)$ & $5.83(0.40)$ \\
\hline $\begin{array}{l}{ }^{*} p<0.005,{ }^{\dagger} p<0.001 \\
\text { Min: Minimum }\end{array}$ & & & & \\
\hline
\end{tabular}


satisfaction with the milk amounts) did not differ between the two groups. Total scores calculated by the summation of the points given for easiness, comfort, satisfaction with the amounts of milk, and maternal general impression were slightly higher for simultaneous breast expression compared to sequential breast expression, with mean standard deviation values of 16.00 (1.88) versus 15.29 (2.07). However, this difference was not at a statistically significant level $(p=0.370)$.

\section{Discussion}

The amounts of milk collected per day and per each period were similar in the simultaneous and sequential breast expression groups in our study. However, a similar amount of milk was obtained in a shorter time with simultaneous pumping being statistically significant on almost all study days. Mothers in the simultaneous expression group found breast expression procedure easier compared to the mothers in the sequential expression group. There was no difference between the total scores and scores for other parameters.

In an earlier study, we showed that electric pumps were easier to use and more efficient than manual pumps, and infants of mothers who used electric pumps even only during the NICU hospitalization period, reached birth weight earlier and had longer exclusive breast feeding and total breast feeding duration in the long term (11). Fewtrell et al. (12) have also found that electrically powered pumps are more efficient than manual pumps.

Simultaneous use of electrically powered breast pumps is more effective and plays a significant role in the continuity of lactation, and increases the amount of milk $(13,14)$. Recently, Prime et al. (15) have shown that simultaneous breast expression is more efficient than sequential breast expression in the total amount of milk collected, lipid and therefore the energy content of the milk. As simultaneous expression yields more milk, the percentage of milk removed was $75 \%$ with simultaneous versus $66 \%$ with sequential pumping. Since healthy breastfed infants remove $67 \%$ of their mothers' milk, simultaneous breast expression increases breast drainage and stimulates milk synthesis. In Prime et al.'s (15) study mothers used the pumps for 15 minutes. However, in our study, mothers used both pumps until they felt that their breasts were totally emptied. The amount of milk obtained via both methods was similar between the two groups. The benefit of the simultaneous method was only the shorter period of breast expression for the mother.

\section{Study Limitations}

In this study, mothers were performing breast expression at home according to instructions and were keeping a diary provided by the researchers. Data was collected for 10 days. Factors that may have effected amount of expressed breast milk were not controlled.

\section{Conclusion}

This study shows that simultaneous breast expression with electrically powered breast pumps helps to achieve similar amounts of milk in a shorter time compared to sequential pumping in newly delivered mothers. Both methods are tolerable and effective. Working mothers may also find this time saving effect very helpful to express milk at work.

\section{Acknowledgements}

We acknowledge Assoc. Prof. Timur Köse from the Ege University Faculty of Medicine, Department of Biostatistics, for his assistance with the statistical analysis.

\section{Ethics}

Ethics Committee Approval: The study was approved by the Ege University Faculty of Medicine Ethical Committee (approval number: 12-4/11).

Informed Consent: All participating mothers gave a written informed consent.

Peer-review: Externally peer-reviewed.

\section{Authorship Contributions}

Surgical and Medical Practices: Ö.A.K., N.C., B.Y.A., S.T., M.Y., M.A., N.K., Concept: M.A., N.K., Design: Ö.A.K., M.Y., Data Collection or Processing: Ö.A.K., N.C., B.Y.A., S.T., Analysis or Interpretation: Ö.A.K, B.Y.A., Literature Search: Ö.A.K, Writing: Ö.A.K, N.K.

Conflict of Interest: No conflict of interest was declared by the authors.

Financial Disclosure: The authors declared that this study received no financial support.

\section{References}

1. Section on Breastfeeding. Breastfeeding and the use of human milk. Pediatrics 2012;129:827-41.

2. Schurr P, Perkins EM. The relationship between feeding and necrotizing enterocolitis in very low birth weight infants. Neonatal Netw 2008;27:397-407.

3. Pineda R. Direct breast-feeding in the neonatal intensive care unit: is it important? J Perinatol 2011;31:540-5.

4. Hurst N, Engebretson J, Mahoney JS. Providing Mother's Own Milk in the Context of the NICU: A Paradoxical Experience. J Hum Lact 2013;29:366-73.

5. Flaherman VJ, Lee HC. "Breastfeeding" by feeding expressed mother's milk. Pediatr Clin North Am 2013;60:227-46.

6. Friend D, Chertok IR. Evaluation of an educational intervention to promote breast pump use among women with infants in a special care nursery in Kenya. Public Health Nurs 2009;26:339-45.

7. Hill PD, Aldag JC, Chatterton RT. Effects of pumping style on milk production in mothers of non-nursing preterm infants. $J$ Hum Lact 1999;15:209-16.

8. Sisk PM, Lovelady CA, Dillard RG, Gruber KJ. Lactation counseling for mothers of very low birth weight infants: 
effect on maternal anxiety and infant intake of human milk. Pediatrics 2006;117:67-75.

9. Hopkinson J, Heird W. Maternal response to two electric breast pumps. Breastfeed Med 2009;4:17-23.

10. Zinaman MJ, Hughes V, Queenan JT, Labbok MH, Albertson B. Acute prolactin and oxytocin responses and milk yield to infant suckling and artificial methods of expression in lactating women. Pediatrics 1992;89:437-40.

11. Genc B, Sen A, Akisu M, Bekler C, Kultursay N. Supporting breast milk intake in premature infants. Bulletin of Ege Pediatrics 1999;6:13-5.

12. Fewtrell M, Lucas P, Collier S, Lucas A. Randomized study comparing the efficacy of a novel manual breast pump with a mini-electric breast pump in mothers of term infants. J Hum Lact 2001;17:126-31.

13. Groh-Wargo S, Toth A, Mahoney K, Simonian S, Wasser T, Rose $\mathrm{S}$. The utility of a bilateral breast pumping system for mothers of premature infants. Neonatal Netw 1995;14:31-6.

14. Hill PD, Aldag JC, Chatterton RT. The effect of sequential and simultaneous breast pumping on milk volume and prolactin levels: a pilot study. J Hum Lact 1996;12:193-9.

15. Prime DK, Garbin CP, Hartmann PE, Kent JC. Simultaneous breast expression in breastfeeding women is more efficacious than sequential breast expression. Breastfeed Med 2012;7:442-7 